\title{
Meintur fyrirvari Íslands við 5. gr. Norður- Atlantshafssamningsins
}

\author{
Sigurjón Njarđarson, ML-nemi á alpjóđasviđi lagadeildar Háskólans í \\ Reykjavík. \\ Bjarni Már Magnússon, lektor viđ lagadeild Háskólans í Reykjavík.
}

\begin{abstract}
Útdráttur
Við aðild Íslands að NATO virðast íslenskir ráðamenn talið sig hafa gert fyrirvara við kjarnaákvæði Norður-Atlantshafssamningsins - sem kveður á um að árás á eitt aðildarríki jafngildi árás á pau öll - 1́ kvöldverðarræðu í tilefni af undirritun hans. Áratugum síðar virðist enn eima eftir peim pankagangi að einhverju leyti. Đær hugrenningar eiga sér pó enga stoð í pjóðarétti. Eins og rakið verður stangast slíkur fyrirvari á við ýmis formskilyrði og efnisreglur sem pjóðaréttur setur um fyrirvara. Petta leiðir til pess að Ísland er bundið af Norður-Atlantshafssamningnum með nákvæmlega sama hætti og önnur aðildarríki NATO.
\end{abstract}

Efnisorð: NATO; Norður-Atlantshafssamningurinn; pjóðaréttur; fyrirvarar.

\section{Iceland's Alleged Reservation to Article 5 of the North Atlantic Treaty}

\section{Abstract}

When Iceland became a party to NATO, the Icelandic government seems to have believed that it made a reservation to the core obligation of the North Atlantic Treaty - the "one for all and all for one" obligation - in a speech held during a dinner celebrating its signature. A few decades later, this belief prevails, to some extent, in Icelandic politics. This opinion has no substance in international law. As is discussed, the reservation does not conform to formal and substantive requirements that international law makes to reservations. Conse-

\author{
Icelandic Review of Politics and Administration Vol 12, Issue 1 (67-80) \\ (C 2016 Contacts: Sigurjón Njarđarson, sigurjonn12@ru.is and Bjarni Már Magnússon, bjarnim@ru.is \\ Article first published online June 21st 2016 on http://www.irpa.is \\ Publisher: Institute of Public Administration and Politics, Gimli, Sæmundargötu 1, 101 Reykjavík, Iceland \\ Stjórnmál \& stjórnsýsla 1. tbl. 12. árg. 2016 (67-80) Fræđigreinar \\ (C) 2016 Tengiliđir: Sigurjón Njarđarson, sigurjonn12@ru.is og Bjarni Már Magnússon, bjarnim@ru.is \\ Vefbirting 21. júní 2016 - Birtist á vefnum http://www.irpa.is \\ Útgefandi: Stofnun stjórnsýslufræđa og stjórnmála, Gimli, Sæmundargötu 1, 101 Reykjavík \\ DOI: http://dx.doi.org/10.13177/irpa.a.2016.12.1.4 \\ This work is licensed under a Creative Commons Attribution 3.0 License.
}


quently, Iceland is bound by the North Atlantic Treaty in the same way as other member states.

Keywords: NATO; North Atlantic Treaty; international law; reservations.

\section{Inngangur}

Norður-Atlantshafsbandalagið (North Atlantic Treaty Organisation (NATO)) var stofnað árið 1949 við undirritun Norður-Atlantshafssamningsins (North Atlantic Treaty 1949). Ísland var eitt af stofnríkjum bandalagsins. Stjórnmála- og sagnfræðingar hafa gert sampykkt Norður-Atlantshafssamningsins góð skil síðustu áratugina en pað hlýtur að vekja furðu að lögfræðingar hafa lítið fengist við viðfangsefnið, sérstaklega par sem málið er að mörgu leyti lagalegs eðlis. Hér verður reynt að gera örlitla bragarbót á og fjallað um efni sem hefur ekki verið fjallað um áður í akademískum skrifum lögfræðinga. Grein pessi fjallar um meintan fyrirvara sem Bjarni Benediktsson, páverandi utanríkistáðherra, setti við lykilákvæði samningsins, p.e. 5. gr. hans, í kvöldverðarboði sem haldið var á undirskriftardeginum. Í stuttu máli kveður ákvæðið á um, að árás á eitt aðildarríki jafngildi árás á pau öll. Lagt verður mat á hvort fyrirvarinn standist pau skilyrði sem pjóðaréttur setur um fyrirvara og hvort hann hafi gildi sem slíkur að pjóðarétti.

Notast er við hefðbundin lögfræðileg vinnubrögð við rannsóknina sem byggja á lagalegum pósitívisma, p.e. réttarheimildir eru rannsakaðar, svo sem pjóðréttarsamningar, og dómar skoðaðir auk fræðiskrifa af sviði pjóðaréttar. Auk pess er reynt að varpa ítarlegra ljósi á hvaða hugmyndir bjuggu að baki fyrirvaranum eftir skoðun á einkaskjalasafni Bjarna Benediktssonar páverandi utanríkisráðherra.

\section{Stofnun NATO}

Pólitískt landslag heimsins gjörbreyttist á fyrri hluta 20. aldar. Gömlu stórveldin, einkum Bretland, Frakkland og Pýskaland, létu verulega á sjá. Valdatómarúmið sem skapaðist var fyllt af tveimur ólíkum sambandsríkjum, Bandaríkjunum og Sovétríkjunum. Áður en seinni heimsstyrjöldinni lauk voru samskipti stórveldanna orðin verulega stirð og fljótlega eftir að henni lauk voru pau komin að frostmarki. Stigvaxandi spenna í Evrópu og ótti ráðamanna vesturveldanna við sovéska ásælni leiddi til stofnunar NATO árið 1949.

Varnir Íslands breyttust með afgerandi hætti pegar Bretar hernámu Ísland 10. maí 1940. Var par kominn erlendur her með pað að markmiði að verja landið og mikilvægar siglingaleiðir fyrir árásum. Bandaríkin tóku við vörnum landsins 7. júlí 1941 og voru hér með hernaðarviðbúnað, bæði hermenn og önnur hergögn fram til ársins 1946 pegar Keflavíkursamningurinn (Exchange of notes... 1946) var undirritaður (Hannes Jónsson 1989, 216-224). Pá var kominn upp sú staða að Ísland var í raun og veru varnarlaust með öllu. Á árunum 1948-1949 hófust preifingar milli ráðamanna Íslands, Noregs, Svípjóðar og Danmerkur um norrænt varnarbandalag (Burkman 1952, 20). Hugmyndir um hvernig slíkt samstarf ætti að líta út voru aldrei fullmótaðar en pó var ljóst að forsenda slíks samstarfs væri náið samband, samráð og jafnvel hernaðarleg aðstoð í formi hergagna og ráđgjafar af hendi Bandaríkjanna (Burkman 1952, 12-14). 
Í desember 1948 settu bandarísk stjórnvöld sig í samband við Bjarna Benediktsson, páverandi utanríkisráðherra Íslands, með pað í huga að bjóða Íslendingum að gerast stofnríki að hinu nýja varnarbandalagi (Björn Bjarnason 2001, 12). Fór Bjarni fljótlega eftir pað til Bandaríkjanna við priðja mann til viðræðna um væntanlegan samning (Björn Bjarnason 2001, 25). Lagði íslenska sendinefndin höfuðáherslu á sérstöðu Íslands, verandi herlaus pjóð sem vildi lifa í friði við allar pjóðir. Höfuðakkur annarra stofnríkja, og pá helst Bandaríkjanna, af pví að fá Ísland inn í bandalagið var landfræðileg staðsetning Íslands. Í hugsanlegri styrjöld stórveldanna væri sterk staða á Íslandi algert lykilatriði í peim átökum, einkum er varðar birgðaflutninga (Hannes Jónsson 1989, 241). ${ }^{1}$

Í aprílmánuði 1949 skrifuðu fulltrúar Belgíu, Kanada, Danmerkur, Frakklands, Ítalíu, Lúxemborgar, Hollands, Noregs, Portúgals, Bretlands, Bandaríkjanna og Íslands undir Norður-Atlantshafssamninginn og var par með Atlantshafsbandalagið stofnað. ó verður að gæta að pví að sú fjölljjóðlega stofnun sem NATO er í dag varð ekki til við undirritun samningsins árið 1949. NATO byrjaði að taka á sig núverandi mynd í kjölfar Kóreustríðsins örfáum árum eftir tilurð Norður-Atlantshafssamningsins (Judt 2010, 151). Frá peim tímapunkti hefur bandalagið fyrst og síðast birst umheiminum sem varnar- og öryggissamstarf.

Í árpúsundir var ekki spurt hvort stríð væri löglegt eða ekki. Með tilurð 4. mgr. 2. gr. Sáttmála hinna sameinuðu pjóða (Charter of the United Nations 1945, hér eftir stofnsáttmáli SD) voru árásarstríð bönnuð sem löglegt úrræði í alpjóðasamskiptum. Stríð eru pó ekki útilokuð. Skiptir par mestu 51. gr. stofnsáttmálans. Đar er kveðið á um að pað sé órjúfanlegur réttur hvers ríkis að grípa til varna ef á pað er ráðist, hvort sem ríki gerir pað sjálft eða í samstarfi við önnur ríki. Með pessu er gert ráð fyrir að ríki geti myndað með sér bandalög og pannig tryggt varnir hvert annars. Á pessum grunni er varnarbandalag ríkja undir hatti Norður-Atlantshafssamningsins stofnað (Hegedüs o.fl 2010, 33).

\section{Einn fyrir alla og allir fyrir einn}

Hugsunin á bak við 5. gr. Norður-Atlantshafssamningsins er í grunninn einföld. Árás á eitt aðildarríki jafngildir árás á pau öll. Beiting vopnavalds er pó ekki afdráttarlaus niðurstaða verði eitt aðildarríki fyrir árás heldur ráðstafanir sem „nauðsynlegar“ eru til að koma á og varðveita frið á svæðinu. Ákvæðið verður jafnframt að skoða út frá 4. mgr. 2. gr. stofnsáttmála SD um ólögmæti vopnaðrar valdbeitingar í samskiptum ríkja. Fimmta greinin er kjarnagrein Norður-Atlantshafsamningsins og hornsteinn bandalagsins (NATO, “collective defence” 2014). Hún hljóðar svo:

Aðilar eru sammála um, að vopnuð árás á einn peirra eða fleiri i Evrópu eða Norður-Ameríku skuli talin árás á pá alla; fyrir pví eru peir sammála um, ef slík vopnuð árás verður gerð, að pá muni hver peirra, í samræmi við rétt pann til eigin varnar og sameiginlegrar, sem viðurkenndur er í 51. grein sáttmála Sameinuðu pjóðanna, aðstoða aðila, pann eða pá, sem á er ráðizt, með pví að gera pegar í stað hver um sig 


\section{STJÓRNSÝSLA}

og ásamt hinum aðilunum pær ráðstafanir, sem hann telur nauðsynlegar, og er par með talin beiting vopnavalds, til pess að koma aftur á og varðveita öryggi Norður-Atlantshafssvæðisins.

Tilkynna skal Öryggisráðinu tafarlaust allar pvílíkar vopnaðar árásir og allar ráðstafanir, sem gerðar eru vegna peirra. Hætta skal slíkum ráðstöfunum, pegar Öryggisráðið hefur gert pær ráðstafanir, sem nauðsynlegar eru til pess að koma á aftur og varðveita alpjóðafrið og öryggi.

Eins og áður hefur verið komið inn á er Norður-Atlantshafssamningurinn saminn á grunni stofnsáttmála SP og er 5. gr. fyrrnefnda samningsins byggð á 51. gr. pess síðarnefnda sem segir að ekkert í peim sáttmála útiloki hinn „ævarandi“ (e. inheritable) rétt ríkja til sjálfsvarnar gegn vopnaðri árás (e. armed use of force). Er par gengið skrefinu lengra en í 4. mgr. 2. gr. stofnsáttmála SЬ. Баð ákvæði kveður á um að ríki eigi að leitast við аð forðast að beita valdi (e. use of force) og varast hótanir um valdbeitingu. Í dómi Alpjóðadómstólsins í máli Níkaragúa gegn Bandaríkjunum frá árinu 1986 (ICJ Rep 1986, 3) sagði (i 176. mgr.) að 51. gr. væri með orðalagi sínu „ævarandi réttur til sjálfsvarnar“ að vísa til pess að sá réttur væri á einhvern hátt náttúrulegur og par með væri ljóst að sá réttur byggði á venju sem eldri væri stofnsáttmálanum.

Augljóst er að „,hefðbundin“ beiting vopnavalds (s.s. innrás landhers yfir landamæri ríkis og flugskeytaárásir) telst sjálfsvarnarástæða, bæði skv. venju og einnig 51. gr. stofnsáttmála SP, og par af leiðandi ástæða til virkjunar 5. gr. Norður-Atlantshafssamningsins. Raunveruleikinn er hins vegar ekki svarthvítur og ýmis grá svæði eru til staðar. Hlutirnir byrja að flækjast verulega pegar fjölpjóðleg hryðjuverkasamtök koma inn í myndina. Í tilfelli hryðjuverkaárásanna á Bandaríkin árið 2001 féllst Öryggisráð Sా (2001) á að sú árás væri vopnuð árás í skilningi 51. gr. stofnsáttmála SP með ályktun nr. 1368. Vegna pessa voru aðgerðir gegn Afganistan til að uppræta Al-Qaeda-hryðjuverkasamtökin réttlættanlegar að pjóðarétti.

\section{Fyrirvarinn við fimmtu grein}

Íslensk stjórnvöld tóku talsverðan pátt í viðræðum um norrænt varnarbandalag fyrri hluta árs 1948. Á sama tíma voru ríki Vestur-Evrópu að reyna sjóða saman sitt eigið bandalag. Öll viðleitni Evrópuríkjanna í átt til aukins varnarsamstarfs, hvaða nafni sem pað átti að nefnast, var pó að öllu leyti háð pátttöku Bandaríkjanna og gríðarlegs stuðnings peirra (Judt 2010, 149-154). Eins og sjá má af minnisblöðum Bjarna Benediktssonar frá sumrinu 1948 til haustsins voru hagsmunir Bandaríkjanna hér á Íslandi töluverðir. Birtust peir aðallega í hinum ýmsu tilfæringum í málum sem vörðuðu aðstöðuna sem Bandaríkjamenn höfðu komið upp hérlendis á stríðsárunum. Pann 7. desember 1948 beiðist Butrick, páverandi sendiherra Bandaríkjanna á Íslandi, fundar með Bjarna Benediktssyni par sem hann tilkynnti að ráðgert væri að bjóða Íslandi að verða meðal stofnríkja í Norður-Atlantshafsbandalaginu (Bjarni Benediktsson 7. desember 1948).

prátt fyrir að Norður-Atlantshafssamningurinn sé fjölpjóðlegur samningur var 
samningsaðili Íslands aðeins Bandaríkin. Slíkt fyrirkomulag er vitaskuld ekki hefðbundið fyrir fjölpjóðlega samninga. Samkvæmt minnisblaði sendiráðs Bandaríkjanna á Íslandi frá 5. janúar 1949 var á peim tímapunkti ekki búið að móta öll ákvæði pess sem seinna varð Norður-Atlantshafssamningurinn. Pó voru grunnatriðin komin á hreint, m.a. um samvinnu í varnarmálum og að öll aðildarríki skuli gera „pað sem nauðsynlegt er til að tryggja öryggi á svæðinu“ ef á eitt ríkjanna er ráðist (Sendiráð Bandaríkjanna á Íslandi 1949). ${ }^{2}$ Aldrei var um eiginlegar samningaviðræður að ræða af hálfu Íslands. Samkvæmt minnisblaðinu er Íslandi boðið að gerast aðildarríki að Norður-Atlantshafssamningnum ásamt Danmörku og Portúgal en ekki að taka pátt í samningu ákvæða hans.

Á fundinum pegar petta tiltekna minnisblað er afhent er strax sleginn tónninn í peim aðalatriðum sem samningsaðilar áttu eftir að ræða á komandi vikum og mánuðum. „Án pess að vilja segja nokkuð um málið á pessu stigi, “ spyr Bjarni Benediktsson hvort Íslendingar pyrftu að hervæðast og svo hvort skilyrt væri að hér myndi her vera með festu á friðartímum. Butrick svarar pessu að sér sýndist ekki vera um slíkar skuldbindingar að ræða, án pess pó að slá neinu á föstu um slíkt. „Aðalatriðið væri flugvöllurinn“ (Bjarni Benediktsson 5. janúar 1949).

Í framhaldi af pessum preifingum fór sendinefnd á vegum ríkisstjórnarinnar til Bandaríkjanna til viðræðna um Norður-Atlantshafssamninginn og til að gera grein fyrir sjónarmiðum Íslands. Sendinefndina skipuðu Bjarni Benediktsson, Eysteinn Jónsson menntamálaráðherra og Emil Jónsson, viðskipta- og samgöngumálaráðherra. Fyrsti fundur hennar með bandarískum ráđamönnum átti sér stað 14. mars 1949. Dann fund sat m.a. Dean Acheson, sem pá var nýlega orðinn utanríkisráðherra Bandaríkjanna. Sýnir pað með afgerandi hætti hversu mikilvægt Bandaríkin töldu að Ísland yrði aðili аð NATO. Á pessum fundi var íslenskum ráðamönnum fyrst gerð grein fyrir efnislegri útfærslu samningsins og samkvæmt sama minnisblaði er ekki annað að sjá en a.m.k. hafi sá texti sem síðar varð 3. og 5. gr. samningsins verið nánast fullkláraður. Eins og áður hefur verið tæpt á var ekki inn í myndinni að Íslendingar gæetu gert neinar efnislegar athugasemdir við ákvæði samningsins. Bandarísku embættismennirnir lögðu pess í stað áherslu á með hvaða hætti Norður-Atlantshafssamningurinn myndi snerta Ísland. Acheson utanríkisráðherra tók t.d. fram að Íslendingar ákvæðu sjálfir framlag sitt ef til virkjunar 5. gr. kæmi „bona fide“ og að ekki kæmi sjálfkrafa til stríðsyfirlýsingar jafnvel pótt á eitt aðildarríkjanna yrði ráðist.

Hér verður að staldra sérstaklega við orðalag Acheson um að aðgerðir hvers ríkis fyrir sig séu „,bona fide“. Eins og síðar verður rakið, er parna hugsanlega komið að kjarna 5. gr. Norður-Atlantshafssamningsins, p.e. að jafnvel pótt viðbrögð hvers ríkis séu ekki nákvæmlega útlistuð í ákvæðinu pá er búist við einhverjum viðbrögðum. Alger hjáseta var og er vafalítið ekki valmöguleiki. Á framhaldsfundi sömu aðila var t.d. ræddur sá möguleiki að Íslendingar létu af hendi togara! Taldi einn fundarmanna, Hickerson, að slíkt væri „ekki alveg óhugsandi, að ráðið [pað sem síðar varð Norður-Atlantshafsráðið] mundi gera einhverjar tillögur í pá átt ef pað pætti sanngjarnt" (Sendinefnd Íslands... 14. mars 1949). Seinna var pað nefnt að líklegasta niðurstaðan yrði pó sú að Íslendingar létu af hendi aðstöðu. 


\section{STJÓRNSÝSLA}

Á pessum sama fundi er meginefni pessarar greinar fyrst nefnt. Bjarni Benediktsson spyr hvort Íslendingar geti gert sérstakan formlegan fyrirvara um ,að Ísland hefði engan her og sérstöðu pess að öðru leyti bæri að virða“ (Sendinefnd Íslands... 14. mars 1949). pessum hugmyndum Bjarna var parna pegar hafnað á peim forsendum að ef eitt ríki myndi gera fyrirvara við samninginn myndu fleiri fylgja í kjölfarið og vilja gera sína eigin fyrirvara. Var pað og nefnt að „,érstaða“ Íslands væri öllum aðildarríkjum vel kunn og yrði hún virt af peim öllum.

Viðræður sendinefndarinnar við bandaríska embættismenn snerust aðallega um hvaða viðbúnað Íslendingar pyrftu að hafa til reiðu vegna samningsins, s.s. hver ætti að hafa yfirumsjón með slíkum viðbúnaði og hvort hér pyrfti erlent herlið en pví voru allir fulltrúar íslensku sendinefndarinnar mjög andvígir (Sendinefnd Íslands... 15. mars 1949 og Sendinefnd Íslands 16. mars 1949). Samkvæmt minnisblaði sendinefndarinnar frá 16. mars 1949 um fund hennar með Hickerson og Hulley steig hún pó býsna ákveðið til jarðar í peim efnum að reyna að koma á formlegum fyrirvara við Norður-Atlantshafssamninginn. Bjarni spyr berum orðum hvort „algerlega væri útilokað“ að gera formlegan fyrirvara er myndi snúa að pví að Ísland ,[...] hvorki hefði né ætlaði sér að hafa her" (Sendinefnd Íslands... 16. mars 1949, 5). Í svari sínu við pessari spurningu Bjarna spyr Hickerson hvort pað dygði ekki að sendinefndin gerði grein fyrir pví heima á Íslandi að pessi sérstaða hefði verið skýrð og að allir aðilar Norður-Atlantshafssamningsins viðurkenni pessa sérstöðu „,fyllilega“. Bjarni lét ekki undan og kvaðst Hickerson pá purfa að leita með málið til Acheson utanríkisráðherra en kvaðst ekki bjartsýnn á niðurstöðuna sökum fordæmisins sem slíkur fyrirvari myndi gefa. Samkvæmt minnisblaðinu um fundinn prefa fundarmenn um pennan fyrirvara eitthvað áfram uns Achilles, sem kallaður hafði verið á fundinn, vakti athygli á pví „að líklega myndu peir sem undirrituðu samninginn hver um sig halda smá ræðu, og væri hugsanlegt, að hægt væri að koma hinu íslenska orðalagi að í slíkri ræðu“" (Sendinefnd Íslands... 16. mars 1949, 6). Hickerson bauðst síðar á fundinum til pess að slíkur fyrirvari 1 ræðuformi yrði ræddur nánar við Acheson en Bjarni kvað pað ekki tímabært.

Fyrirvarans var ekki getið beinum orðum í minnisblaði um fund sendinefndarinnar með Acheson daginn eftir 17. mars 1949. Par var fallist á að getið yrði um sérstaka stöðu Íslands (e. special position) í fréttatilkynningu um viðræðurnar. Pá var einnig lýst yfir af hálfu Bandaríkjanna:

1) Að ef til ófriðar kacmi mundu bandalagspjódirnar óska svipadrar aðstödu á Íslandi og var i sidasta strijdi [seinni heimsstyrjöldinni], og pad myndi algörllega vera á valdi Íslands själfs, bvenar sú ađ̀stada yròi látin i té.

2) Að allir adrir samningsadilar hefơu fullan skilning á sérstöơu Íslands.

3) Að vidurkennt vari að Ísland heföi engan her og atladi ekki að stofna her.

4) Að ekkei kami til mála, að erlendur her eða herstödvar yrơ á Íslandi á friðartimum.

Eftir að viðræðum lauk virðist hafa farið af stað atburðarás í Bandaríkjunum sem lýkur 
með pví að Acheson utanríkisráðherra sendi símskeyti til bandaríska sendiráosins á Íslandi 26. mars 1949, par sem hann gerir grein fyrir peirri afstöðu sinni að Íslendingar eigi ekki að nefna neitt í ræðu sinni um varanlegan fyrirvara á aðild sinni, eingöngu eigi peir að vísa til núverandi ástands sem uppi er, enn fremur eigi að forðast orðalag eins og að „Ísland geti ekki lýst yfir stríði““ $(1976,3)$. Frá skeyti Acheson og fram til pess að Alpingi sampykkir að gerast stofnaðili NATO gerist fátt og taldi Bjarni Benediktsson að pað „,póf“ sem varð á málinu hafi verið vegna pess að Bandaríkjastjórn hafi verið að kynna aðstæður Íslendinga fyrir öðrum ríkjum er ætluðu að undirrita hann (Matthías Johannessen 1969, 10-11). Нvað sem öðru líður pá var Ísland eitt peirra ríkja sem undirrituðu Norður-Atlantshafssamninginn og eins og til stóð hélt Bjarni Benediktsson ræðu af tilefni undirritunarinnar í umræddu kvöldverðarboði í Washington DC að viðstöddum utanríkisráðherrum hinna NATO-stofnríkjanna, par sem gerð var grein fyrir „fyrirvaranum“ með svohljóðandi hætti:

Ísland hefur aldrei farið með hernaði gegn nokkru landi, og sem vopnlaust land hvorki getum við né munum segja nokkurri pjóð stríð á hendur, svo sem við lýstum yfir, er við gerðumst ein af Sameinuðu pjóðunum. Staðreynd er, að við getum alls ekki varið okkur gegn neinni erlendri vopnaðri árás (îsl. pýðing skv. fréttatilkynningu utanríkisráðuneytisins 4. apríl 1949). ${ }^{3}$

Af pessum orðum Bjarna má leiða að íslensk stjórnvöld hafi talið sig undanskilin beinni aðild að stríðsátökum sem kunni að brjótast út komi til virkjunar kjarnaákvæðsins til allrar framtíðar. Frá undirritun Norður-Atlantshafssamningsins hefur lítið heyrst um fyrirvarann og hvaða gildi hann á að hafa nema pá eftir árásirnar 11. september 2001 á Bandaríkin eins og vikið verður að hér á eftir. Bjarni Benediktsson sjálfur getur fyrirvarans í áður tilvitnuðu viðtali í Morgunblaðinu og af ummælum hans að dæma virðist hann telja að um gildan fyrirvara sé að ræða og að sum ríki, án pess að pað sé útskýrt hver pau eru, hafi talið að skuldbindingar Íslands vegna samningsins hafi verið minni en annarra ríkja (Matthías Johannessen 1969, 10-11).

Í pessu samhengi er athyglisvert að líta til pingsályktunar peirrar par sem aðild Íslands að NATO er sampykkt. Í athugasemdum við ályktunina (Alpt. 1948-1949) er vísað í fyrrnefndar viðræður íslensku sendinefndarinnar við bandarísk stjórnvöld. Haft er eftir Acheson að hernaðaraðgerðir af hálfu hernaðarlauss ríkis kæmu ekki til greina. Af minnisblöðum um fundi samninganefndarinnar við bandarísk yfirvöld að dæma verður ekki séð hvernig hægt er að komast að peirri niðurstöðu. Acheson lagði pvert á móti áherslu á að aðgerðir ríkja vegna virkjunar 5. gr. væru í góðri trú eins og áður segir. Útilokað er að lesa í orð hans, skv. áður tilvitnuðum minnisblöðum, á pann veg að alger hjáseta væri möguleiki.

\section{Lögmæti fyrirvara Íslands}

Vínarsamningurinn um milliríkjasamninga (Vienna Convention on the Law of Treaties 1969) skilgreinir fyrirvara með eftirfarandi hætti í d-lið 2. gr: 


\section{STJÓRNSÝSLA}

„Fyrirvari“ er einhliða yfirlýsing ríkis, hvernig sem hún er orðuð og án tillits til formlegs heitis hennar, við undirritun, fullgildingu, sampykki, upptöku eða aðildar að milliríkjasamningi par sem pað undanpiggur sig eða breytir bindandi áhrifum tiltekinna ákvæða eða ákvæðis hvað pað ríki varðar (ísl. pýðing greinarhöfunda). ${ }^{4}$

Norður-Atlantshafssamningurinn var undirritaður 1949 pannig að Vínarsamningurinn um milliríkjasamninga frá 1969 var vitaskuld enn ekki kominn til sögunnar. Vínarsamningurinn er meginréttarheimildin um tilurð, túlkun og endalok milliríkjasamninga. Hvorki Ísland né Bandaríkin eru aðilar að samningnum. Ríki eru hins vegar almennt talin bundin af honum par sem hann er fyrst og síðast lögfesting á venjurétti (Gardiner 2008, 122), sbr. dóm Alpjóðadómstólsins frá 25. september 1997 í máli Ungverjalands gegn Slóvakíu (ICJ Reports 1997, 7, mgr. 46). Vegna pessa er ekki hægt að horfa fram hjá efni Vínarsamningsins pegar milliríkjasamningar eru teknir til skoðunar prátt fyrir að peir séu tilkomnir fyrir tilurð Vínarsamningsins. Samkvæmt 19. gr. Vínarsamningsins eru fyrirvarar heimilir nema eftirfarandi komi til;

a) Fyrirvarinn er óheimill skv. viðkomandi samningi,

b) Samningurinn heimilar eingöngu tiltekna fyrirvara eda

c) Fyrirvarinn gengur gegn megintilgangi eða markmiðum samningsins.

Norður-Atlantshafssamningurinn inniheldur ekkert ákvæði um fyrirvara, p.e. pað er ekkert ákvæði í honum sem heimilar pá sérstaklega eða bannar. Ef við bregðum stækkunarglerinu á yfirlýsingu Bjarna Benediktssonar í fyrrgreindu kvöldverðarboði pá fól hún í sér pá afstöðu að kæmi til stríðsreksturs vegna virkjunar 5. gr. samningsins pá muni Ísland ekki verða aðili að pví stríði (e. „we neither can or will declare war against any nation“). Í pessu samhengi er rétt að árétta að stríðsyfirlýsingar tíðkast varla í nútímanum. Enginn greinarmunur er gerður á stríðsyfirlýsingu og beitingu vopnavalds í nútíma pjóðarétti. Fyrst og síðast er horft til framkvæmdar ríkja pegar metið er hvort beiting valds hafi átt sér stað (Sloane 2009, 65).

Pá hlýtur að vakna spurningin hvort hægt sé að líta á yfirlýsingu Bjarna sem gildan fyrirvara að pjóðarétti? Ef skoðuð eru skilyrði fyrirvara eins og venja hafði skipast um er stutta svarið: Nei, alls ekki. prjú grundvallaratriði gera pað að verkum að ekki er hægt að líta á fyrirvara Íslands við 5. gr. Norður-Atlanthafssamningsins sem gildan. Í fyrsta lagi uppfyllir fyrirvarinn ekki pað formskilyrði pjóðaréttar, sem birtist í 1. mgr. 23. gr. Vínarsamningsins, að fyrirvarar purfi að vera skriflegir. Á peim 20 árum sem samningurinn var í smíðum var aldrei efast um petta skilyrði enda ýmsar hagkvæmisástæður fyrir slíku fyrirkomulagi sem tengjast miðlun upplýsinga um fyrirvarann til annarra samningsríkja og skráningu hans (Pellet \& Schabas 2011, 598-599). Í öðru lagi eiga allir pjóðréttarsamningar skv. 1. mgr. 102. gr. stofnsáttmála SP sem aðildarríki samtakanna gerast aðilar að að vera skrásettir hjá skrifstofu aðalframkvæmdastjóra SP eins fljótt og unnt er og skulu peir birtir af henni. Fyrirvarar eru jafnframt skráðir af skrifstofun- 


\section{STJÓRNSÝSLA}

ni. Norður-Atlantshafssamningurinn var birtur af skrifstofunni en enginn fyrirvari er skráður við samninginn. Í priðja lagi er tekið fram í ráðgefandi áliti Alpjóðadómstólsins frá 1951 um fyrirvara við gerð samnings gegn hópmorðum frá 1948 (Genocide Convention Case 1951) að fyrirvarar megi ekki ganga gegn megintilgangi eða markmiðum samnings. pessi niðurstaða rataði inn í fyrrnefndan c) lið 1. mgr. 19. gr. Vínarsamningsins. Ef fyrirvari sem kveður á um að ríki sé ekki skuldbundið að fullu af 5. gr. Norður-Atlantshafssamningsins gengur ekki gegn megintilgangi hans pá er vandfundinn sá fyrirvari við nokkurn samning sem gerir pað. Đeim sem komu að Norður-Atlantshafssamningnum fyrir Íslands hönd áttu pví ekki að vera í neinum vafa með pað að lagalegt gildi ræðu Bjarna af tilefni undirritunarinnar var ekkert.

Engin formleg viðbrögð voru við ræðu Bjarna Benediktssonar. Telja verður líklegt að pað stafi af pví að ekkert aðildarríki taldi að um formlegan fyrirvara væri að ræða enda eru fyrirvarar vanalega orðaðir með mun skýrari og nákvæmari hætti. Að minnsta kosti er ljóst að Bandaríkjamenn voru ekki hrifnir af fyrirvarahugmyndum Íslands. Bjarni Benediktsson segir reyndar sjálfur frá að Norðmenn hafi sýnt jákvæð viðbrögð við kvöldverðarræðu sinni (Matthías Johannessen 1969, 10-11). Рað hefur hins vegar enga lagalega pýðingu.

Auk pessara atriða er rétt að benda á tvær reglur sem búnar voru til í undirbúningi Vínarsamningsins um milliríkjasamninga sem skipta hér máli prátt fyrir að pær teldust ekki pjóðréttarvenja á peim tíma sem Norður-Atlantshafssamningurinn var saminn. Í 2. mgr. 20. gr. Vínarsamningsins um milliríkjasamninga kemur fram að ef um er að ræða grundvallarforsendu varðandi efni og markmið samnings purfi öll aðildarríki að veita formlegt sampykki sitt fyrir fyrirvara. Ljóst er að ákvæðið á við í tilfelli 5. gr. Norður-Atlantshafssamningsins. Auk pess er ljóst að aðildarríkin veittu aldrei formlegt sampykki sitt fyrir fyrirvaranum hvað pá öll aðildarríkin. Í 3. mgr. 20. gr. Vínarsamningsins segir að pegar milliríkjasamningur setur á laggirnar alpjóðastofnun verði, ef ekki er mælt á annan veg, fyrirvarinn að vera sampykktur af valdbæru stjórnvaldi innan stofnunarinnar. Norður-Atlantshafssamningurinn setti á laggirnar NATO. Ekkert bendir til pess að „,fyrirvarinn" hafi verið ræddur innan NATO hvað pá verið sampykktur.

prátt fyrir að „fyrirvarinn“ hafi ekkert lagalegt vægi virðast Bandaríkjamenn hafa tekið tillit til afstöðu Íslands. Í skýrslu bandaríska utanríkisráðuneytisins frá 1949 sem varðaði samskipti Bandaríkjanna og Íslands kemur eftirfarandi fram:

Out of regard to Icelandic nationalist sentiment and the country's limited resources of men and materials, Iceland's adherence to the North Atlantic Treaty was accepted with certain reservations insisted upon by the Icelandic Government. Thus, Iceland will not be asked to receive foreign troops or to provide bases manned by foreign troops during peacetime, nor will it be required in the event of war to make a purely military contribution to the defense of the area covered in the Treaty. It is envisaged that the role of Iceland in the event of a future war will be limited to providing bases for North Atlantic defense troops. 


\section{STJÓRNSÝSLA}

Af pessu að dæma er lítill vafi á pví að markmið sendinefndarinnar hafi „de facto“ náðst. Баð verður pó að athugast í pessu samhengi að hér er um túlkun einungis einnar aðildarpjóðar að ræða. Раð verður pó vitaskuld að taka tillit til pess að Bandaríkin hafa ávallt verið lykilaðildarríki Atlantshafsbandalagsins. Túlkun bandarískra yfirvalda á stöðu Íslands hafði, og hefur enn, geysilega mikið vægi.

\section{Nútíminn}

Kalda stríðið leið undir lok án pess að 5. gr. væri nokkurn tímann virkjuð og fram til haustsins 2001 var fátt í spilunum sem benti til að hún yrði virkjuð í bráð. Фað breyttist allt 11. september 2001 pegar ráðist var á Tvíburaturnana í New York og á Pentagon í Washington D.C. Innan við sólarhring frá árásunum tilkynnti Robertson lávarður, páverandi aðalframkvæmdastjóri NATO, bandarískum stjórnvöldum að ef árásin ætti rætur sínar að rekja til ríkis utan NATO, væri litið svo á að um vopnaða árás á eitt af bandalagsríkjum NATO væri að ræða - 5. gr. Norður-Atlantshafssamningsins var orðin virk (NATO, „Collective defence“ 2014).

Hvað pýddi pað fyrir Ísland? Eins og orðalag 5. gr. ber með sér er hverju ríki frjálst að ákveða sitt framlag sjálft. Má pví gagnálykta að lágmarksskuldbinding hvers ríkis fyrir sig er að gera eitthvað meira en ekki neitt. एó verður að hafa í huga að skv. 4. gr. Norður-Atlantshafssamningsins er ríkjum skylt að hafa með sér samráð á vettvangi Norður-Atlantshafsráðsins og kynna par áætlanir sínar. Samkvæmt handbók NATO (NATO A-Z pages 2014, 54) verður hvert ríki fyrir sig að hafa í huga að meginmarkmiðið sé að koma aftur á friði og öryggi á Norður-Atlantshafssvæðinu. Norður-Atlantshafsráðið sendir aldrei neitt frá sér nema með einróma sampykki. Рað er pví ljóst að vettvangur er til staðar fyrir önnur aðildarríki NATO að beita stjórnmálalegum prýstingi ef eitthvert aðildarríkjanna dregur lappirnar í framlagi sínu til aðgerða vegna virkjunar 5. gr. Norður-Atlantshafssamningsins.

Í skýrslu sem páverandi utanríkisráðherra Íslands, Halldór Ásgrímsson, flutti á Alpingi vegna árásanna á Bandaríkin og viðbrögðin við peim lýsti hann yfir að Ísland styddi aðgerðir Bandaríkjamanna til að hafa hendur í hári peirra sem ábyrgð bæru á árásunum á Tvíburaturnana (Alpt. 2001 - 2002, B. deild, 1. ræða). Áhugavert er að Steingrímur J. Sigfússon, páverandi formaður Vinstri hreyfingarinnar - græns framboðs, spyr utanríkisráðherra sérstaklega um stöðu fyrrnefnds „,fyrirvara“ við 5. gr. Norður-Atlantshafssamningsins og auðsætt að í hans huga liggi enginn vafi á pví að sá fyrirvari sé í fullu lagalegu gildi (Alpt. 2001 - 2002, B deild, 1. ræða). Svarar páverandi utanríkisráðherra pví til að hann hefði ekkert á móti pví að svara Steingrími J. en hefði ekki til pess neinn tíma! Auk pess bætti hann við: „,[...] en minni á að við hljótum að meta utanríkispólitíska hagsmuni okkar í ljósi núverandi aðstæðna en ekki aðstæðna 1945 og 1949 (Alpt. 2001 - 2002, B deild 2. ræða). ${ }^{\text {"5 }}$

Á leiðtogafundi aðildarríkja Atlantshafsbandalagsins í Prag 2002 má segja að skrefið hafi verið tekið að fullu frá „Atlantshafsbandalagi kalda stríðsins“ yfir í Atlantshafsbandalag nútímans. Meðal pess sem kom fram í yfirlýsingu, sem gefin var út að henni lokinni, var að koma ætti á herliði sem væri ávallt til taks og gæti komist hratt milli heimshluta. 
Auk pess kom fram að NATO myndi stórefla styrk sinn á öllum vígstöðvum m.a. til pess að mæta hinni nýju hryðjuverkaógn ásamt pví að friðargæsluverkefni NATO (ISAF) yrði eflt (Norður-Atlantshafsráðið 2002). Í kjölfarið skuldbatt Ísland sig til að kosta ýmis verkefni er tengdust flutningi búnaðar og mannafla með flugi fyrir 300 milljónir kr. og að stórauka pátttöku sína í friðargæsluverkefnum NATO í Afganistan (Ólafur D. Stephensen 2003, 42-43).

Á ráðstefnu í Bonn í desember 2001 var komið á fót sérstöku verkefni sem átti að hafa pað hlutverk að aðstoða afgönsk yfirvöld við að tryggja öryggi og stöðugleika í Afganistan. Í kjölfarið gaf Öryggisráð SP út ályktun nr. 1386 pann 20. desember 2001 og á peim grunni hófst starf alpjóðaliðs í Afganistan. Hlaut verkefnið nafnið „International Security Assistance Force“ (hér eftir ISAF) og var í fyrstu aðallega á forræði Bandaríkjanna og Bretlands. Pann 11. ágúst 2003 tók NATO við forræði verkefnisins. ISAF er ekki 5. gr. verkefni og pví verður að gæta að pví að draga ekki of víðtækar ályktanir pegar skuldbindingargildi 5. gr. er skoðað. ISAF verður hins vegar ekki fyllilega aðskilið frá virkjun 5. gr. og petta tvennt verður að skoðast í samhengi (Gorka 2006).

Eftir leiðtogafundinn í Prag 2002 fjölguðu íslensk stjórnvöld friðargæsluliðum sínum úr 25 í 50 og var umfangsmesta verkefni íslensku friðargæslunnar í Afganistan umsjón alpjóðaflugvallarins í Kabúl en við henni tók íslenska friðargæslan 1. júní 2004 (NATO, “NATO assumes control...” 2004). ISAF var bundið af Genfarsamningunum, um vernd fórnarlamba vopnaðra átaka milli ríkja frá 1949 sem gilda í stríðsrekstri (Bellal, Giacca og Casey-Maslen 2001). Petta á jafnvel við pótt að ISAF hafi ekki verið í hreinum „árásaraðgerðum“ á sama hátt og herir Bandaríkjanna og Bretlands.

Í athugasemdum við frumvarp til laga um íslensku friðargæsluna nr. 73/2007 var að hluta til viðurkennt að störf íslenskra friðargæsluliða væru ekki eingöngu ,borgaralegs eðlis“, p.e. að friðargæsluliðar geti purft að taka pátt í verkefnum sem eru „hernaðarlegs“ eðlis. Einnig að friðargæsluliðar gætu purft að klæðast merktum einkennisfatnaði og lúta tignarröð eins og hún gengur fyrir sig í herjum. Jafnframt byrfti í einhverjum tilvikum að færa íslenska friðargæsluliða undir stjórn erlendra aðila og par með viðurkenna peirra aðgerðarreglur (e. rules of engagement). Hvorki í lögunum né athugasemdum með frumvarpinu er tekið fram með beinum hætti hvort íslenskir friðargæsluliðar teljist hermenn eða óbreyttir borgarar að pjóðarétti í slíkum tilvikum.

Баð er grundvallarregla í pjóðarétti að hermenn aðgreini sig frá almenningi. Birtist reglan m.a. í 3. mgr. 44. gr. viðbótarbókunar I frá 1977 við Genfarasamningana. Ísland er aðili að viðbótarbókuninni. Í 1. mgr. 43. gr. segir að hersveitir séu „hvers konar skipulagðar hersveitir, flokkar og deildir undir stjórn foringja sem ber ábyrgð á athæfi undirmanna sinna gagnvart peim aðila.“ Auk pess kemur fram að hersveitir skuli „,háðar innra agakerfi par sem meðal annars skal framfylgt peim pjóðréttarreglum sem við eiga um vopnuð átök. “Vandséð er að sjá að einstaklingur í herklæðum sem lýtur tignarraðar innan hers og er skylt að hlúta aðgerðarreglum hans geti talist annað en hermaður í skilningi Genfarsamningana. Almenningur er skilgreindur með neikvæðum hætti p.e. peir sem ekki eru hermenn eru almenningur, sbr. 50. gr. viðbótarbókunar I. Jafnvel pótt einhverjir liðsmenn hersveitar sinni „,borgaralegum“ störfum sem ekki eru af hernaðar- 


\section{STJÓRNSÝSLA}

legum toga eru peir engu að síður hermenn í hersveit í slíkum tilvikum. Bollaleggingar íslenskra ráðamanna breyta par engu um. Segja má pví að pað hafi tekið tæplega sex áratugi fyrir íslensk stjórnvöld að fara frá pví að reyna gera fyrirvara við 5. gr. NorðurAtlantshafssamningsins yfir í að opna á möguleikann í landslögum að vera með hermenn í friðargæsluverkefnum erlendis.

\section{Niðurstöður}

Баð er fullkomlega ljóst að „fyrirvari“ Íslands við 5. gr. Norður-Atlantshafssamningsins hefur ekkert lagalegt gildi. Hann var ekki skriflegur, ekki skráður og gengur gegn megintilgangi NATO. „Fyrirvarinn“ var í raun og sann ekkert annað en pólitísk yfirlýsing um pað sem allir vissu, eða máttu vita að Ísland væri verulegum takmörkum bundið pegar kæmi að stríði og stríðsrekstri. Aukin heldur verður að taka tillit til hins viðkvæma ástands sem uppi var á íslenska stjórnmálasviðinu pegar „fyrirvarinn“ er skoðaður. Á árinu 1949 var pað enn lykilatriði í huga íslensks almennings að Íslendingar væru friðsöm pjóð í alpjóðasamfélaginu og rökrétt er að álykta að í raun og sann hafi „fyrirvaranum“ ekki síst verið beint til íslensks almennings, honum til friðpægingar.

Eftir situr pá hverjar lagalegar skuldbindingar Íslands vegna 5. gr. Norður-Atlantshafssamningsins eru? Stutta svarið er að greinin hefur fullt lagalegt gildi gagnvart Íslandi eins og öðrum aðildarríkjum. Komi til stríðsreksturs vegna virkjunar 5. gr. Norður-Atlantshafssamningsins er Ísland aðili að pví stríði. Ekki er í boði að standa á hliðarlínunni í slíku tilfelli. Prátt fyrir herleysið er enginn ,afsláttur“ gefinn af 5. gr. Herleysið takmarkar eftir sem áður pau úrræði sem Íslendingar hafa til að standa við skuldbindingar sínar.

\section{Aftanmálsgreinar}

1 Í 10. kafla bókar sinnar fer Hannes yfir áhugaverðar staðreyndir sem undarlegar gætu talist í ljósi pess hversu áfjáðir Bandaríkjamenn voru í að Ísland gerðist aðili að NATO. M.a. kemur í ljós að Bandaríkin töldu nær engar líkur á að Íslandi stæði veruleg ógn utan frá (ytra öryggi) en aftur á móti væri ástand innanlands mjög viðkvæmt og ekki útilokað að öfl hliðhöll Sovétmönnum gætu reynt að ná völdum með valdbeitingu. Detta er mjög forvitnilegt sérstaklega í ljósi pess að ekkert í Norður-Atlantshafssamningnum veitir aðildarbjóðum heimild til að hlutast til um innanríkismál hvors annars.

2 „Providing that in event of armed attack on any party within area all parties would take such action as might be necessary to restore and assure security of area...."

3 Ræða Bjarna var haldin á ensku og fyrirvarinn orðast svo: „My country has never waged war on any country and as an unarmed country we neither can or will declare war against any nation as we stated when entering the United Nations. In truth we are quite unable to defend ourselves from any foreign armed attack."

4 Á ensku er greinin svohljóðandi: ,,(d) "Reservation” means a unilateral statement, however phrased or named, made by a State, when signing, ratifying, accepting, approving or acceding to a treaty, whereby it purports to exclude or to modify the legal effect of certain provisions of the treaty in their application to that State."

5 раð er ekki par með sagt að Steingrímur J. hafi gleymt „fyrirvaranum“. Í fyrirspurn á Alpingi veturinn eftir, sem varðaði boðun á fund Norður-Atlantshafsráðsins vegna virkjunar Tyrkja á 4. gr. Norður-Atlantshafssamningsins, minnti Steingrímur utanríkisráðherra aftur á fyrirvarann og líkt og áður talaði Halldór í kringum efnið og vék ekkert að gildi „fyrirvarans“ í svari sínu (Alpt. B deild 2002-2003). 


\section{Heimildaskrá}

Acheson, D. (1976) „Bréf til sendiherra Bandaríkjanna á Íslandi 26. mars 1949“, Djódviljizn, 15 apríl.

Alpióðadómstóllinn (1951). Reservations to the Convention on Genocide (Ráðgefandi álit). Skoðað 18. mars 2016 á: http://www.icj-cij.org/docket/files/12/4283.pdf.

Alpjóðadómstóllinn (1984). Military and paramilitary activities in and against Nicaragua (Nicaragua v.

USA). ICJ Rep. 3. 392.

Alpjóðadómstóllinn (1997). Case concerning the Gabcikovo-Nagymaros project (Hungary v. Slovakia)

ICJ Rep. 692, 7.

Alpt. 1948-1949, A deild, pskj. 499 - 177 mál

Alpt. 2006-2007, A.deild, pskj. 566 - 443 mál.

Alpt. 2009-2010, A-deild, pskj. 1358 - 568 mál.

Alpt. 2001-2002, B deild, 35. mál, 46 - 1. ræða Halldórs Ásgrímssonar.

Alpt. 2001-2002, B deild, 35. mál, 46, 74 - 2. ræða Halldórs Ásgrímssonar.

Alpt. 2001-2002, B deild, 35. mál, 46, 55 - 1. ræða Steingríms J. Sigfúsonar.

Alpt. 2002-2003, B deild, 414 mál, 3188 - 3. ræða Steingríms J. Sigfússonar.

Aust, A. (2007) Modern treaty law and practice. Cambridge: Cambridge University Press.

Bandaríska utanríkisráðuneytið (1949). Policy statement of the Department of State. Foreign relations of the United States, Volume IV, Western Europe, Document 386.

Bellal, A., Giacca, G. og Casey-Maslen, S. (2001). „International law and armed non-state actors in Afghanistan“, International review of the red cross, 93(881). Sótt 18. mars 2016 á https://www.icrc.org/ eng/assets/files/review/2011/irrc-881-bellal-giacca-casey-maslen.pdf.

Bjarni Benediktsson (1948). Minnisblað um fund með G. Knox pann 11. nóvember 1948 (Borgarskjalasafn Reykjavíkur, Einkaskjalasafn nr. 360, Askja 2-10, örk 4) Bjarni Benediktsson (1948). Minnisblað um fund með Richard P. Butrick, sendiherra Bandaríkjanna á Íslandi, 7. desember 1948 (Borgarskjalasafn Reykjavíkur, Einkaskjalasafn nr. 360, Askja 2-10, örk 4).

Bjarni Benediktsson (1949). Minnisblað um fund Richard P. Butrick, sendiherra Bandaríkjanna á Íslandi, 5. janúar 1949 (Borgarskjalasafn Reykjavíkur, Einkaskjalasafn nr. 360, Askja 2-10, örk 5).

Bjarni Benediktsson (1949). Ræða við undirritun Norður-Atlantshafssamningsins, (Washington 4. apríl 1949).

Björn Bjarnason (2001). Í bita kalda strídsins greinar og ritgerðir, Reykjavík: Nýja bókafélagið

Burbank, L. B. (1952). „Scandinavia and N.A.T.O.“ (júlí 1952) 23 Current History (pre-1986), 20.

Charter of the United Nations, (Undirritaður 26. júní 1945, tók gildi 24. október 1945) 1 UNTS XVI. Stj. tíð. A, 91/1945. Síðari breytingar á sáttmálanum birtar í stj.tíð. C, 9/1965, 10/1196, 7/1973 og $21 / 1973$.

Exchange of notes constituting an Agreement between the United States of America and Iceland terminating the Defense Agreement of 1 July 1941 and providing for interim use of Keflavik Airport (7. október 1946) 12 UNTS, 163 (Keflavíkursamningurinn).

Gardiner, R. (2008). Treaty Interpretation, Oxford: Oxford University Press.

Geneva Conventions Relative to the Protection of Civilian Persons in Time of War, (Genf 12. ágúst 1949, tók gildi 21. október 1950) 75 UNTS 287. Stj.tíð. C. 16/1965. Gorka, S. L. V. (2006) „Invocation in context" NATO review, sumar 2006, sótt 18. mars 2016 á http://www.nato.int/docu/ review/2006/issue2/english/art1.html.

Hannes Jónsson (1989). Íslensk sjálfstađis- og utanrikismál frá landnámi til vorra daga. Reykjavík: Félagsmálastofnun.

Hegedüs, Z. (ritstj.) o. fl. (2010). NATO Legal Deskbook (2. útg.) Office of the legal adviser, Allied command transformation staff element Europe, Rafbók sótt 18. mars 2016 á https://info.publicintelligence.net/NATO-LegalDeskbook.pdf.

Judt, T. (2010). Postwar A History of Europe since 1945, London: Vintage Books

Matthías Johannessen (1969). „Degar Ísland undirritaði Atlantshafssáttmálann“ Morgunbladið, 3. apríl, 10. 


\section{STJÓRNSÝSLA}

NATO (2004). NATO assumes control of Kabul international airport. (Fréttatilkynning) Brussel 1. júni (uppfært 3. nóvember 2008). Sótt 18. mars 2016 á: http://www.nato.int/cps/en/natohq/news_20819. htm? selectedLocale $=$ en.

NATO (2014). „,collective defence“, 11. nóvember. sótt 18. mars 2016 á: http://nato.int/cps/en/natohq/topics_110496.htm?selectedLocale $=$ en.

NATO (2014). NATO A-Z Pages, NATO Public Diplomacy Division. (rafbók) sótt 1. apríl 2016 á: http://www.nato.int/cps/en/natohq/topics_118210.htm

NATO (2015). „ISAF's mission in Afghanistan (2001-2014)“ 13. janúar 2015. sótt 18. mars 2016 á: http://www.nato.int/cps/en/natolive/topics_69366.htm.

Norður-Atlantshafsráðið (2002). „Prague summit declaration“, 21. nóvember 2002. Sótt 18. mars 2016 á: http://www.nato.int/DOCU/pr/2002/p02-127e.htm.

North Atlantic Treaty (4. apríl 1949, tók gildi 24. ágúst 1949) 34 UNTS 243 (NATO) stjtíð. A, 96/1949.

Ólafur P. Stephenssen (2003). „Loforð um loftflutninga og eflingu friðargæslu“, Morgunbladið 22. nóvember. 42-43.

Pellet, A \& Schabas, W. „Article 23 Procedure regarding reservations“ í O. Corten \& P. Klein (ritstj.), The Vienna Convention on the Law of Treaties (594-625). Oxford, Oxford University Press.

Protocol Additional to the Geneva Conventions of 12 August 1949, and relating to the Protection of Victims of International Armed Conflicts (Protocol I), (Genf 8. júní 1977, tók gildi 7. desember 1978) 1125 UNTS 3.

Sendinefnd Íslands í Bandaríkjunum vegna athugunar á aðild Íslands að Norður-Atlantshafssamningnum (1949). Minnisblað um fund með Dean Acheson, Charles E. Bohlen og John D. Hickerson 14. mars 1949, (Borgarskjalasafn Reykjavíkur, Einkaskjalasafn nr. 360, Askja 2-10, örk 5).

Sendinefnd Íslands í Bandaríkjunum vegna athugunar á aðild Íslands að Norður-Atlantshafssamningnum(1949). minnisblað um fund með John D. Hickerson og Hulley (fornafn kemur ekki fram) 15. mars 1949, (Borgarskjalasafn Reykjavíkur, Einkaskjalasafn nr. 360, Askja 2-10, örk 5).

Sendinefnd Íslands í Bandaríkjunum vegna athugunar á aðild Íslands að Norður-Atlantshafssamningnum (1949). minnisblað um fund með John D. Hickerson og Hulley (fornafn kemur ekki fram) 16. mars 1949, (Borgarskjalasafn Reykjavíkur, Einkaskjalasafn nr. 360, Askja 2-10, örk 5).

Sendinefnd Íslands í Bandaríkjunum vegna athugunar á aðild Íslands að Norður-Atlantshafssamningnum (1949), minnisblað um fund með Dean Acheson 17. mars 1949, (Borgarskjalasafn Reykjavíkur, Einkaskjalasafn nr. 360, Askja 2-10, örk 5).

Sendiráð Bandaríkjanna á Íslandi (1949) "Memorandum for the information of the Prime Minister and the Foreign Minister”, 5. janúar. (Borgarskjalasafn Reykjavíkur, Einkaskjalasafn nr. 360, Askja 2-10, örk 5).

Sloane, R. D. (2009). „The Cost of Conflation: Preserving the Dualism of Jus ad Bellum and Jus in Bello, the Contemporary Law of War", The Yale journal of international law 34, 8-14

Utanríkisráðuneytið (1949). Ræða Bjarna Benediktssonar utanríkisráðherra við undirskrift Atlantshafssáttmálans, 4. apríl 1949.

Vienna Convention on the Law of Treaties, (1969). Undirritaður 23. maí 1969, tók gildi 27. janúar 1980 1155 UNTS 331.

Öryggisráð SP (2001). Ályktun 1368, 12. September, UN Doc S/Res/1368. 